\title{
Cash-Cow into the Purse of Malaysian Property Investors: Students Housing Investment
}

\author{
Zubairu Abubakar Ghani ${ }^{1,2}$, Noralfishah Suleiman ${ }^{2}$ \\ ${ }^{1}$ Abubakar Tafawa Balewa University \\ Tawafa Belewa Way, P. M. B. 0248, Bauchi, 740272, Nigeria \\ ${ }^{2}$ Universiti Tun Hussein Onn Malaysia \\ 101 Parit Raja, Batu Pahat, Johor, 86400, Malaysia
}

DOI: $10.22178 /$ pos. $25-5$

JEL Classification: 018

Received 15.07.2017

Accepted 12.08.2017

Published online 24.08.2017

Corresponding Author:

Zubairu Abubakar Ghani,

zubairughani@yahoo.co.uk

(c) 2017 The Authors. This

article is licensed under a

Creative Commons

Attribution 4.0 License

(c) (1)
Abstract. Growing demand for higher education (HE) and increasing students enrolment in higher education institutions (HEI) has been a global issue especially in the last three decades and housing the growing student population has become a dilemma for all concern HEls stakeholders. Globally increasing demand for HE and enrolment has long been not corresponding with student housing supply. Most HEls provide housing accommodation for a small proportion of their total students' population while the majority depend on private rental sector for their alternative housing. In most of the HEls neighbouring community residential houses were rented out to students. These houses are not sufficient to accommodate the teaming student population because the market is dominated by traditional small-scale private developers. However, with the continuing expansion and demand for $H E$, increasing enrolment and increasing students housing demand, the study highlighted and suggested for private investors to pull up and dig into student housing investment. This will ameliorate and fill the shortfall created by inadequacy of HEls housing provision. Student housing investment is a resilient market, lucrative venture and guaranteed cash cow.

Keywords: student housing; higher education institutions (HEls); student population; student enrolment; student housing demand; private housing market.

\section{INTRODUCTION}

Students are special group of people, most of them young men, who were given admission for study in Higher Education Institutions (HEI) in their respective fields of studies and levels. Similarly, [1] described students as those who are admitted into colleges to study. Usually this group of people leaved their parents' homes and live in the student housing in either on-campus or off-campus.

In recent years, colleges of higher learning experienced high growth in population as enrolment increases. Student enrolment in HEI is increasing tremendously all over the world more especially in the UK, USA, Ireland, China, India, Malaysia $[2,3,4,5,6,7,8,9,10,11,13]$. This is supported by [13] and [7] that, student number has risen globally and students overall enrolment are postulated to increase by 32 million over the next ten (10) years. Accordingly [14] reported that, global number of higher education (HE) students is anticipated to grow to ' 263 million by 2025'.

Despite this demographic growth of students in HEIs, provisions of student housing is not congruent to the population growth, most of the students will not get accommodation in the HEI students housing and thus had to find alternative housing in the private housing rental market. Many studies have reported that, it has been a tradition of many HEIs that, the enrolment is much higher than the available housing facilities for students $[15,4,16,10,17,18,2,1,19,20,8$, $21,22,6]$. This causes constraints and pressure on the existing student housing facilities in many 
HEIs across the world and it is increasingly becoming difficult especially for HEIs to provide accommodation for all students despite few other students may prefer to live in their family house or refuse to live on-campus. At the beginning of every academic session when new students were enrolled, most HEIs with their existing students housing, accommodate a small segment (20-30\%) of their total students population, majority of the students will not get accommodation in HEIs housing system. This necessitates many other students to scout for alternative housing where opportunities exist outside the campus in private housing market $[2,3,23,4,1$, $19,21,10,6,22,24,8]$.

\section{LITERATURE REVIEW}

Being students are special group of people with a common interest; they are also special consumers of housing like any other special areas or institutions. Such special areas or institutions include military barracks, care homes, hospitals, prisons and camps, to mention but a few. These special areas or institutions' housing requirements are slightly different, based on their peculiarities from the general family house. The differences are basically in their respective housing facilities requirements more especially in the areas of supportive facilities. However, housing in terms of basic requirements, the special areas and family housing are obviously the same. According to [3] family and student housing are distinctive where the later embody basic facilities like bedroom with other shared facilities such as bathroom, toilets, laundry, kitchen, students' lounges and cafeteria. Furthermore, student housing security tenure and freedom are limited compared to family housing.

Student housing, is the housing unit for college students to live for the purpose of studies where many young men leave their homes and parents, reside in student housing without parental monitoring and control which is a different experience for new life style, learn how to compromise with other students, endure, tolerant, shared space and facilities and live independently which was described as a transitional phase towards adulthood $[12,25,6]$. Also student housing offers chances for students to develop attitudes of living and working together in the college environment and to understand further ethos of the college and life [26]. Furthermore, [27] reported that student housing is important in motivating stu- dents' academic performance. Hence student housing is impacting on students' comfort, convenience and safety, therefore, conducive student housing in HEIs cannot be overemphasized because students are expected to be comfortable and in a sound state of mind to excel in their academic endeavours which can be achieved by a good student housing system. In support of this [2] expressed that, student housing is an important physical facility that influenced in expanding students' intellectual proficiencies of their academic mission and also help to achieve responsible citizenship and leadership.

Globally there is progressive growth of HEIs following the unprecedented growth in the youth demography age 18-24 years old. Higher education (HE) has been growing rapidly in both developed and developing countries especially in the last three decades where many young men are graduating from high schools and gaining access into colleges and universities $[7,9,4,2,11$, $16,12,21,6]$. In the last three decades student enrolment has radically raised globally and is expected to increase as [6] described, more "children of baby boomers" are graduating from high schools. Aol Real Estate Contributor [21] reported that student enrolment has raised from 98 million in 2000 to 165 million in 2011 globally with an average increase of 6 million yearly and it is expected to increase to around 195 million students by 2020. While, [13] submits that the total number of HEIs student enrolment is expected to reach 263 million globally in 2025 . Further, [4] opined in 2011, a record of 21.6 million students was enrolled in American postsecondary institutions; this has shown a growth of over $40 \%$ since 2000. Similarly, [16] stated that in Malaysia, in 2009 there were approximately about 1.5 million students and expected to increase in years to come as expected $50 \%$ or more of the Malaysian youth aged 18-30 year olds would gain access to HEIs. It was observed that HEIs Students population in Malaysia has been increasing consistently from 664,402 in 2002 to 1.134 million in 2010 with an average increase of 58,717 annual enrolments. More so, the Ministry of Education Malaysia [28] reported that, HEIs student enrolment in 2014 was 560,359 in public universities alone and estimated 1.5 million total enrolments for both public and private universities in 2014 .

These entire scenarios, implies commensurate increase in demand and pressure on the existing HEIs facilities. Despite all these growth in stu- 
dents' number, the provision of students' accommodation is not matching with the growth which led to the constraints and stretching the existing housing facilities. As [4] positioned, the increase in the number of college students along with the expansion of HEIs presented challenges for the provision of student housing in the United States and the rest of the Western world. The residential real estate news of the World Property Journal also wrote in their June, 4th 2014 edition, that many university cities in the UK have sufficient student housing deficit. In many universities there is significant or gross shortfalls in student housing that compelled many students to rent residential quarters outside their campuses. By implications, growth of students' population in HEIs with no corresponding provisions of housing facilities resulted in intensifying shortage and increase in student housing demand in rental market. This trend of student housing development and rapid enrolment making sufficient shortage of student housing will have negative impact on students' comfort, convenience, performance and safety [2]. In the face of growing global students' enrolment in HEIs, student accommodation has become one of the teething problems faced by HEIs especially in the developing countries [1].

\section{METHODOLOGY}

This paper begins with a survey of the literature of related work from journals and other source materials available. The methodology adapted in this study is qualitative and qualitative study allow the use of one or combination of research instruments observation, interviews, documents and audio-visual materials as [29] suggested. The study adopted document analysis as suggested by [30], [31] and [32] if a circumstances seem to be thorny to take a complete field surveys, therefore, the study should employ secondary data to takes advantage of the existing data. S. G. Naoum [33] and B. L. Berg \& H. Lune [34] opined this type of data collection relies on availability of data and convenience that are easily accessible. In this case secondary data are easier to source and use, therefore, the authors take advantage of existing sources of data and studies where relevant information are taken. Basically the study employs secondary data to highlight student housing pressure in Malaysian HEIs and the need for provision from private investors to supplement HEIs' student housing. Due to non- availability of the actual figure of HEIs housing system capacity to the authors at the time, some assumptions were applied in the determination of HEIs student housing needs. This is followed by a conclusion towards filling the gap created by HEIs' housing system.

\section{RESULT AND DISCUSSION}

\section{Student housing in Malaysia}

In Malaysia, the population is steadily growing right from late 1950 to date. This can be attested from the country's demographic evidences where in 1957 the country's population was 7.3 million. However, the population has doubled to the figures of 13.3 million and 27.0 million by 1980 and 2008 respectively [35]. According to Population Reference Bureau [36], Malaysian population in 2015 stands at 30.8 million and just in 6 years time from 2008-2015, the population increased by over 3 million. These population growths are evident indicator of potentiality for the future demand of educational facilities.

According to M. Muslim [3] HEIs Students population in Malaysia has been increasing tremendously in the past two decades and enrolment stood at 1,134,134 in the year 2010. Similarly, the Ministry of Education Malaysia [28] estimated 1.5 million HEIs student enrolment in 2014 and postulated continuous increase in the future. This is a clear testimony that the student population has been increasing and will continue to increase in the future as more children are graduating from high schools. Table 1, below justified the steady growth of HEIs student enrolment in Malaysia.

Internationalization of HE in particular has motivated the Malaysian government to push ambitions for becoming a HE regional hub in Southeast Asia and citizens were encouraged to study locally rather than abroad to save costs [15, 37]. This serves as an opportunity for HEIs to increase their capacity and position themselves better in the global market of international education. As [38] reported Malaysia has placed internationalization as a key drive for transforming its HE to compete with global class HE providers. For Malaysia to realize its aim of becoming an international education hub by 2025, aimed to have 250,000 international student enrolments into its HEIs. In addition to the local student population seeking enrolment in HEIs, govern- 
ment set a goal of attracting 100,000 international students in 2010 where in 2009 \& 2010 HEIs recorded 80,750 \& 86,919 international student enrolments respectively with $7.6 \%$ increase toward achieving international education hub. Planned also to increase to 150,000 \& 200,000 by 2015 and 2020 respectively and targeted the foreign student population to grow to 250,000 in 2025 [28, 15, 3, 16, 38]. Therefore, with these, Malaysia is regarded as an emerging candidate in the world class education providers for attracting international students. However, by implication this will increase the demand tempo for HE and will eventually have positive impact on the demand for other educationrelated sector in the country such as student housing.

Table 1 - Higher Education Institution (HEI) Students Enrolment in Malaysia, 2002-2010

\begin{tabular}{|l|r|r|r|r|r|r|r|r|r|}
\hline \multirow{2}{*}{ HEI Type } & \multicolumn{10}{|c|}{ Years } \\
\cline { 2 - 10 } & \multicolumn{1}{|c|}{2002} & \multicolumn{1}{|c|}{2003} & \multicolumn{1}{c|}{2004} & \multicolumn{1}{c|}{2005} & \multicolumn{1}{c|}{2006} & \multicolumn{1}{c|}{2007} & \multicolumn{1}{c|}{2008} & 2009 & \multicolumn{1}{c|}{2010} \\
\hline Public HEI & 281,839 & 294,359 & 293,978 & 307,121 & 331,025 & 382,997 & 419,334 & 437,420 & 462,780 \\
\hline Private HEI & 294,600 & 314,344 & 322,891 & 258,825 & 323,707 & 365,800 & 399,852 & 484,377 & 541,629 \\
\hline TARC & 31,850 & 29,537 & 26,098 & 24,846 & 26,150 & 25,753 & 26,235 & 25,179 & 23,774 \\
\hline Polytechnic & 52,898 & 53,492 & 64,382 & 73,834 & 82,045 & 84,250 & 85,280 & 86,471 & 87,751 \\
\hline $\begin{array}{l}\text { Community } \\
\text { Colleges }\end{array}$ & 3,207 & 6,424 & 8,945 & 9,873 & 11,273 & 14,438 & 17,082 & 17,279 & 18,200 \\
\hline Total & & & & & & & & & \\
\hline
\end{tabular}

Source: [3], [28]

The unprecedented increase in students' population in Malaysia resulted to continuing extension and establishment of HEIs which triggers student housing demand. HEIs provided student housing facilities in Malaysia generally are insufficient and the students' enrolment each year exceeds the available housing accommodation. Therefore, student housing provisions become a challenge for many HEIs thus the situation increases the demand tempo for student housing in the private rental market. According to [39] majority of HEIs students were necessitated to rents housing accommodation in the private housing market. So this is an indication that student population growth has not been corresponding with student housing supply, thereby, making sufficient deficit in HEIs student housing. Consequently, if such trend continues where demand and supply for student housing are by far at parity, the situation will be regarded as student enrolment boom while student housing bust.

It became clear in Malaysia students' population has been growing and is expected to increase in years to come where many of the Malaysian youth will seek and gain access to HEIs. These entire scenarios are by implications, indicating commensurate increase in demand and pressure on the existing HEIs student housing facilities. In the last two decades provisions of student housing facilities are not proportionate to the enrol- ment which widened the gap of adequacy that led to a tremendous increase in student housing demand hence, demand and supply are not corresponding. As M. Muslim [39] concludes that shortage of student housing exists nationwide as the majority of Malaysian HEIs students at the nation's largest institutions live off-campus in the private housing rental market. This concurred with many studies on student housing that shown most of the HEIs student housing facilities are grossly in adequate and provides housing accommodation for only $20-30 \%$ of their total students' population whereas $70-80 \%$ of the students relied on private rental market.

\section{Student housing market}

In the last decade student housing market has been considered as the promising, speedy growing property rental market and guaranteed demand. This is because it offers relatively high yields compared to other property sectors like retails, warehouses and offices. Yields have moved rapidly over the last decade in the wider real estate market and income returns in the sector has exceed the residential investment market as a whole $[40,41]$. Unlike the residential sector, student housing is one of the best performing sectors during the global economic downturn and it is largely unaffected by home market 
prices plummet $[6,21,40]$. It was observed that student housing have lower volatility than multifamily and other property sectors and also provides higher cash return. Student housing now is considered a 'global asset class' therefore, private developers' interest in student housing in UK and USA is not surprising hence, investors generally, are looking for more generous income yielding sectors for investment. Consequently, [24] regarded commercial operators to have been extremely active over the last five years, with the leading players expanding properties by acquiring more stocks, as well as, funding speculative developments in HEIs towns. However, this may not be unconnected with stagnated supply of HEIs student housing to satisfy the demand and a continuing trend of increase in the students' enrolment has created an excellent opportunity for investment and development of student housing market.

In the world student housing market, UK and USA are the leading players, because the market is matured, as dissimilarity to many other countries. As a result of the insufficiency of HEIs' owned student housing, the private investors have taken a great advantage of students demand and are driven into the student housing market not only in the UK and USA, but in many other countries of the world. Student housing is a distinct niche market, for investors and homeowners to invest. It was reported from a survey that in USA 20 private students' house developers have over 167 student properties under construction consisting of over 97,045 beds spaces in 2015 alone [42]. This is because, the waves of student demand adjacent to HEIs campuses is extremely high thus, demand tells much about the likelihood of the better place for investment opportunity in student housing.

It was observed that central London in Europe is the major location for students housing and the total return from the sector grew significantly to $6.7 \%$ between 2010 and 2011. The world student housing sector grew from $\$ 0.8$ billion investment globally in 2009 and hasty to a lofty of $\$ 7.2$ billion in 2013 [43]. Chiefly, the US and UK markets have driven global investment in student housing to reaching an elevation of $\$ 7.2$ billion in 2013. European student housing market predicted gross average yields of $5.5-8.5 \%$ in 2014. Similarly it was observed that major achievable yields in the sector are in the region of $7 \%$ in Spain, Italy and the Netherlands $[14,40]$. In a UK study it was reported that, student hous- ing experienced annual rental growth of $1.6 \%$ and $2.8 \%$ in 2013 and 2014 respectively [44]. Moreover, returns from student housing have been explored to have outperformed all other property sectors since 2011 and student housing recorded total returns of $7.8 \%$ and $10.9 \%$ in 2013 and 2014 respectively; all other properties recorded $5.4 \%$ growth while residential rental rates in particular have remained relatively stagnant in 2013.

In German student housing market, investors' interest has been growing and the sector saw $\$ 185 \mathrm{~m}$ deals in 2013 and over 7,600 units are planned in the top ranking university cities. The average student housing provision rate among the key cities is $13 \%$ and vacancy rates have declined to below $2 \%$ [14]. Student housing has positively shown an upward trend in Germany, the returns are significantly higher which is driven by an increasing demand and it is very attractive alternative investment [45]. Likewise, in Australia, Singapore and India the experience seems to be surging considerably within their student housing sectors, though the market is considered 'immature' when compared to that of the UK and US [46, 9]. According to [9], recently in India, Manipal Integrated Services, build and manage student housings complex in Bangalore with 1,000 rooms to provide housing to around 2,000 students.

For the Malaysian case, still student housing market is relatively new and not matured though some investors are beginning to see the growing viability in student housing market as an investment. It was found that Sunway Monash Residence is a 22-storey apartment block located at three minute walk from Monash University Malaysia campus. The complex is designed to function as a student community, offering 2,114 bedrooms furnished with beds, desks, wardrobes and $\mathrm{Wi}-\mathrm{Fi}$ and the vacancy rates have recorded below $1 \%$ [46]. Also Gromutual Property built and managed student housing located between Multi-Media University and University Technical Malaysia at Emerald Park, Melaka. Despite insufficient supply of student housing and a continuing trend of increases in the students enrolment in Malaysia, Federal Land Development Authority (FELDA) Malaysia through Felda Investment Corporation (FIC) has made two international real estate investments in student housing known as FELDA House Wembley, located in Wembley and FELDA Grand House located in the city of London, UK [47]. Unfortunately, similar 
effort has not been made for the local student housing market as it has been left to be dominated by the traditional (small-scale) actors. Therefore, HEIs inability to accommodate their teaming student population couple with insufficient supply of student housing and a continuing influx of students resulted to continual uptrend in demand which created an excellent opportunity for investment in student housing.

\section{Investment landscape}

Malaysia population is indicating broader base of normal population pyramid where school going age cohort (14 years old and below) constituted 7.8-8.2 million representing $27 \%$ of the Malaysian total population [28]. This is clear evidence that as they are graduating from high schools, future demand for HEIs and students housing will be guaranteed, all things being equal. Similarly the enrolment statistics of both primary and secondary schools suggested that the future demand is on a high side as the population is much greater than the HEIs enrolment in 2015 (1.5 million) see Table 2 below.

Table 2 - Enrolment in Primary and Secondary Schools from 2012-2014

\begin{tabular}{|l|c|c|c|}
\hline \multirow{2}{*}{ School type } & \multicolumn{3}{|c|}{ Years } \\
\cline { 2 - 4 } & 2012 & 2013 & 2014 \\
\hline Primary School & $2,804,405$ & $2,742,169$ & $2,698,883$ \\
\hline $\begin{array}{l}\text { Secondary } \\
\text { School }\end{array}$ & $2,281,224$ & $2,296,189$ & $2,234,621$ \\
\hline
\end{tabular}

Source: [28]

According to Malaysian Education Minister, Datuk Seri Idris Jusoh, Malaysia's higher education is a world class now on par with those of the developed nations like Britain, Germany, US and Australia [48]. University Malaysia is rated the 151st position up from 167th in 2013 in the list of 400 top world institutions in 2014. He further said, now about 135,000 foreign students are confident of studying in Malaysia [48]. Similarly Malaysia is now experiencing a well encouraging scenario where many people are attending the HEI both locally and internationally, is increasing yearly. With this positive drift, Malaysia has successfully gained global recognition and ranked at 11th worldwide top countries in the global education providers by the United Nations Educational, Scientific, and Cultural Organization
(UNESCO) for her attractiveness to international students [49].This will indeed, facilitate the attainment of becoming educational hub by attracting foreign students. The student housing demand from international students will obviously be high as many HEIs are not accommodating foreign students in their housing programme or else Graduate students who require privacy, isolation from general students prefer off-campus housing. International students will provide a big, essential and guaranteed market.

Some scholars have reported investment in student housing is lucrative and promising business that guaranteed demand and return for a long term investment. As M. Garg [9] reported that student housing is one of the most vibrant Indian real estate markets in the foreseen future. Prominent HEIs with dense student population positively affect the demand for student residential houses. Students housing niche is lucrative not only in the developed nations but also in the developing countries the scenario is the same. As it has been observed, private off-campus student housing in the US and UK is matured and very lucrative business with rent rates growth of $7 \%$ between 2004 and 2006 in 64 college towns across the UK. In fact, the future of student housing niche is extremely promising not only an investment, but a competitively high returning asset and also is becoming one of the really important sectors that create job opportunities. The high level of student demand for rental houses will guaranteed good return rates and low void rates, therefore, targeting students rental properties at densely student HEI neighbourhood is an attractive investment. It's a resilient market outperforming other investment sectors, rapid growth with fairly economic recession-proof and proving relatively resilient during the recent economic crisis. It has been observed, student housing market has consistently been one of the best performing rental sectors during the economic meltdown as the demand was unaffected by other sectors market tumble.

Therefore, student housing provides reliable rental returns which is secured by degree and stability of demand, and often tallied by little or no competing supply. Student housing properties experience the lowest incidence of empty properties. Investors/landlords who rent their properties to students are more likely to find tenants and receive rent on time. Students pay upfront, had no problems with rental payment and many investors may even prefer students over families 
because, if the tenants fail to pay, it is more difficult to evict family tenants. Investments in student housing is an attractive property investment option, promising better returns and offer long-term income streams.

Today, the unimaginably high enrolment and demand for student housing has been on the increase yearly in all Malaysian HEIs and as a result of incapability of the HEIs to provide housing to the teaming populace, private housing developers will take advantage of stagnant supply and increasing demand to make an exceptional investment in students housing. It has been observed that private housing developers will contribute to a large proportion of the entire housing stocks for student hence; HEIs provide accommodation to only a small fraction of their students' population. The contribution of private developers in housing delivery cannot be over emphasise thus they accommodate majority of the students. In spite of their efforts in complementing HEIs efforts in housing delivery, they should aim at providing descent and comfortable students housing to the test of their clients.

\section{CONCLUSION}

The needs to provide adequate and good quality students housing should not be over emphasis hence students are expected to be in a sound state of mind to excel in their academic endeavours. However, there is a dire need to ensure that students housing are adequately and qualitatively provided to avoid any possible disruptions to students learning process and to minimize hassles students encountered in trying to get affordable and convenient accommodation at all cost.

It has become clear student housing is one of the best performing rental sectors, a distinct niche market which produces reliable rental income flow secured by intensity and steadiness of de- mand and is often correspond with low levels of competing supply. Student housing properties experienced the lowest incidence of void/empty properties; demand is guaranteed, has lower volatility than other property sectors and provides a higher cash yield. Being resilient nature of student housing market is also regarded as a world asset class.

Student enrolment is the major driver for the student housing demand therefore, rising demand of $\mathrm{HE}$ and increasing enrolment has increased student housing demands in the HEIs towns. It is clear HEIs students housing are limited and the housing system is grossly inadequate to satisfy the growing demands, majority of the students are often forced to find alternative housing accommodation in the private housing rental market. Therefore, filling the gap created by the deficit of HEIs housing system lies in the hands of the private housing developers around the HEIs. As a result of HEIs inability to provide sufficient students housing and a continuing increase in the student enrolment has created an excellent opportunity for investment in student housing. Private housing developers should take the advantage to pull-up in student housing investment in order to meet-up the growing demand for more housing infrastructure. These creates conducive atmosphere for private housing developers to invest in purposely built student housing, a resilient niche market that will guarantee cash cow into their purse.

\section{ACKNOWLEDGEMENT}

We wish to acknowledge Abubakar Tafawa Balewa University Bauchi, Nigeria for graduate fellowship and a special thanks goes to Nigeria Tertiary Education Trust Fund (TET Fund) for fellowship grant intervention which supported this research.

\section{REFERENCES}

1. Nimako, S., \& Bondinuba, F. (2013). Relative importance of student accommodation quality in higher education. Current Research Journal in Social Sciences, 5(4), 134-142.

2. Muslim, M. H., Karim, H. A., \& Abdullah, I. C. (2012). Challenges of Off-Campus Living Environment for Non-Resident Students' Well-Being in UiTM Shah Alam. Procedia - Social and Behavioral Sciences, 50, 875-883. doi: 10.1016/j.sbspro.2012.08.089

3. Muslim, M. H., Karim, H. A., \& Abdullah, I. C. (2013). Well-Being of UiTM Shah Alam Students Living in Off-Campus Environment. Asian Journal of Environmental-Behaviour Studies, 4(13), 147-158. 
4. Spieler, A., Ong, S. E., \& Petrova, M. (2013). Demand for university student housing: An empirical analysis. Journal of Housing Research, 22(2), 141-164.

5. Onwong'a, M. (2012). An assessment of impacts of the growth of hostel accommodation on other land uses: a case study of Ngara west sub-location, Nairobi (Doctoral dissertation, University of Nairobi). Retrieved from http://erepository.uonbi.ac.ke/

6. Zaransky, M. H. (2006). Profit by investing in student housing: Cash in on the campus housing shortage. Chicago: Kalplan Publishing.

7. Powley, T. (2013, June 3). How to invest in students property. Financial Times. Retrieved from https://www.ft.com/content/45dde256-cc39-11e2-9cf7-00144feab7de

8. Rugg, J., Rhodes, D., \& Jones, A. (2000). The nature and impact of student demand on housing markets. York: Joseph Rowntree Foundation.

9. Garg, M., Gupta, K., \& Jha, R. (2014). An empirical study on market research of organized students' housing industry in India. International Journal of ICT and Management, 2(2), 143-154.

10. Garmendia, M., Coronado, J. M., \& Urena, J. M. (2011). University Students Sharing Flats: When studentification Becomes Vertical. Urban Studies, 49(12), 2651-2668. doi: $10.1177 / 0042098011428176$

11. Kenna, T. 2011. Studentification in Ireland? Analysing the impact of students and student accommodation on Cork City. Irish Geography, 44(2-3), 191-213.

12. Khozaei, F., Ayub, N., Hassan, A. S., \& Khozaei, Z. (2010). The Factors Predicting Students' Satisfaction with University Hostels, Case Study, Universiti Sains Malaysia. Asian Culture and History, 2(2), 148-158. doi: 10.5539/ach.v2n2p148

13. Jones Lang LaSalle. (2012). Student housing: a new global asset class. Retrieved from http://www.aninver.com/fotos/file/blog/Global-Student-Housing-Report-November-2012.pdf

14. Savills World Research. (2013, Summer). Spotlight European Student Housing. Retrieved from http://pdf.savills.com/documents/European_Student_Spotlight_2013.pdf

15. Ong, W. M. (2013). Students' Expectations and Perceptions of Service Quality Performance: University student advisors in Australia, Malaysia and Singapore (Doctoral dissertation, RMIT University). Retrieved from https://researchbank.rmit.edu.au/view/rmit:160441/Ong.pdf

16. Omar, D. B., Abdullah, F., Yusof, F., Hamdan, H., Nasrudin, N., \& Abdullah, I. C. (2011). The impacts of off-campus students on local neighbourhood in Malaysia. International Journal of Social, Behavioral, Educational, Economic, Business and Industrial Engineering, 5(10,) 1221-1227.

17. Goglobal Investments Group. (2017). Student Properties for Sale in the UK. Why invest in UK student property? Retrieved July 5, 2017, from

https://www.goglobalinvestments.com/properties/student-property-investments

18. Davidson, M. (2013, August 13). The best place to invest in student property. The Telegraph. Retrieved from http://www.telegraph.co.uk/property/investmentinproperty/10273660/Thebest-places-to-invest-in-student-property.html

19. Nimako, S. G. \& Bondinuba, F. K. (2013). An empirical evaluation of student accommodation quality in higher education. European Journal of Business and Social Sciences, 1(12), 164-177.

20. Collinson, P. (2010, August 21). The best and the worst student accommodation. The Guardian. Retrieved from http://www.theguardian.com/money/2010/aug/21/best-worst-studentaccommodation

21. Gopal, P. (2008, March 13). College towns: Still a smart investment. Retrieved from http://www.primepropertyinvestors.com/businessweek.pdf

22. Alaka, I. N., Pat-Mbano, E. C. \& Ewulum, N. J. (2012). Contributions of Private Hostel Providers to Housing Needs of Imo State University Students, at Ugwuorji-Owerri Nigeria. Canadian Social Science, 8(2), 180-186. doi: 10.3968/j.css.1923669720120802.2755 
23. Munro, M. \& Livingston, M. (2012). Student Impacts on Urban Neighbourhoods: Policy Approaches, Discourses and Dilemmas. Urban Studies, 49(8), 1679-1694. doi: 10.1177/0042098011419237

24. Hubbard, P. (2009). Geographies of Studentification and Purpose-Built Student Accommodation: Leading Separate Lives? Environment and Planning A, 41(8), 1903-1923. doi: 10.1068/a4149

25. Thomsen, J. (2008). Student Housing - Student homes? Aspects of student housing satisfaction (Doctoral thesis). Retrieved from https://brage.bibsys.no/xmlui/bitstream/handle/11250/231116/124643_FULLTEXT02.pdf?se quence $=1 \&$ isAllowed $=\mathrm{y}$

26. Ja'afar, W. (2012, June). Hostel management system (HMS) (Bachelor degree thesis). Retrieved from http://umpir.ump.edu.my/4840/1/WAN_NUR_HIDAYU_WAN_JAAFAR.pdf

27. Hammad, D. B., Musa, J. M., Rishi, A. G., \& Ayuba, I. I. (2013). Criteria for the selection of students' accommodation model in Nigeria tertiary institutions using analytic hierarchy process. Academic Research International, 4(5), 550-556.

28. Ministry of Education Malaysia (2014). Quick Facts 2014: Malaysia Educational Statistics. Retrieved from http://www.moe.gov.my/index.php/en/media/penerbitan/terbitan/bukuinformasi $/$ book/15/1?page=1

29. Gray, D. E. (2014). Doing research in the real world (3rd ed.). London: Sage.

30. Creswell, J. W. (2009). Research design: Qualitative, quantitative, and mixed methods approaches (3rd ed.). Los Angeles: Sage.

31. Bhattacherjee, A. (2012). Social science research: principles, methods, and practices (2nd ed.). Tampa: University of South Florida.

32. Marzbali, M., Abdullah, A., N. Razak, N., \& Tilaki, M. (2011). A Review of the Effectiveness of Crime Prevention by Design Approaches towards Sustainable Development. Journal of Sustainable Development, 4(1), 160-172. doi: 10.5539/jsd.v4n1p160

33. Naoum, S. G. (2007). Dissertation research \& writing for construction students (3rd ed.). New York: Routledge.

34. Berg, B. L., \& Lune, H. (2017). Qualitative research methods for the social sciences (9th ed.). Boston: Pearson.

35. Abdullahi, B. C., \& Aziz, W. N. (2011). The role of private sector participation in achieving anticipated outcomes for low-income group: A comparative analysis of housing sector between Malaysia and Nigeria. African Journal of Business Management, 5(16), 6859-6890.

36. Population Reference Bureau. (2016). 2016 World population data sheet. Retrieved from http://www.prb.org/pdf16/prb-wpds2016-web-2016.pdf

37. Varghese, N. V. (Ed.). (2001). The Impact of the Economic Crisis on Higher Education in East Asia: Country Experiences. Paris: UNESCO and International Institute for Educational Planning.

38. Aziz, A., Siong, H., Tin, L., M. Hamzah, M., \& Abdullah, D. (2011). Responding Towards Increasing International Student Enrolment in Malaysia. In International Higher Education Congress: New Trends \& Issues.

39. Muslim, M. H., Karim, H. A., \& Abdullah, I. C. (2012). Satisfaction of Students' Living Environment between On-Campus and Off-Campus Settings: A Conceptual Overview. Procedia - Social and Behavioral Sciences, 68, 601-614. doi: 10.1016/j.sbspro.2012.12.252

40. Savills World Research. (2017). Spotlight UK student housing. Retrieved from http://pdf.euro.savills.co.uk/uk/spotlight-on/spotlight-uk-student-housing-2017.pdf

41. Savills World Research (2014). Spotlight World student housing. Retrieved from http://pdf.euro.savills.co.uk/residential---other/spotlight-world-student-housing-2014.pdf 
42. Student House Business. (2017). The top developers in student housing. Retrieved 5 July, 2017, from http://www.studenthousingbusiness.com/

43. Rutman, S. (2013, March 13). Lesson for investing in student accommodation. Estate Gazette. Retrieved from http://www.traverssmith.com/media/1298904/lessons_for_investing_in_student_accommodati on.pdf

44. Intelligent Partnership. (n. d.). Student Property: Risks and Reasons to Invest. Retrieved from https://intelligent-partnership.com/research-hub/student-property-risks-reasons-invest

45. Cooper, B. (2013). Investors urged to cast net wider. Property Magazine, 8, 63-65. Retrieved from https://investment-briefings.propertyeu.info/media/investors-urged-cast-net-wider/

46. Karpinski, M. (2015, March 13). Student accommodation in Malaysia. Retrieved from https://www.hotcoursesabroad.com/study-in-malaysia/student-accommodation/studentaccommodation-in-malaysia/

47. The Sundaily. (2016, July 29). Felda launches second student accommodation property in London. Retrieved from http://www.thesundaily.my/node/383852

48. The Rakyat Post. (2015, February 14). Malaysia's Higher Education World Class. Retrieved from http://www.therakyatpost.com/news/2015/02/21/malaysias-higher-education

49. Najib, N., Yusof, N., \& Tabassi, A. (2015). Living in On-campus Student Housing: Students' Behavioural Intentions and Students' Personal Attainments. Procedia - Social and Behavioral Sciences, 170, 494-503. doi: 10.1016/j.sbspro.2015.01.052 